\title{
ПРОЯВИ ОРГАНІЗОВАНОЇ ЗЛОЧИННОСТІ ПРАЦІВНИКІВ ПРАВООХОРОННИХ ОРГАНІВ
}

IГНАТОВ Олександр Миколайович - доцент кафедри кримінального права та кримінології Кримського юридичного інституту Одеського державного університету внутрішніх справ, кандидат юридичних наук, старший науковий співробітник

УДК 343.9

Акиентировано внимание на существовании организованнъгх форм преступности работников правоохранительных органов. Установленъ и проанализированъ некоторье основнъие бакторь детерминации данного вида преступлений.

Ключові слова: організована злочинність, правоохоронні органи, детерміначія.

Постановка проблеми

Ситуація що склалася свідчить, що темпи та масштаби зростання організованої злочинності в Україні на сьогодні не усвідомлені в повній мірі. На користь цього свідчить як відсутність належного законодавчого забезпечення протидії організованій злочинності та відсутність ефективних діючих спеціальних програм протидії ій, так й відсутність стурбованості суспільства щодо значного зростання кількості проявів організованої злочинної діяльності та збільшення кількості злочинних об'єднань представників державної влади, зокрема працівників правоохоронних органів.

Для того, щоб пізнати будь-яке явище чи процес, розглянути його характеристики і форми проявів, необхідно вивчення їх складових. Злочинність, їі окремі види і групи в цьому відношенні теж не $\epsilon$ винятком. Особливості будь-якого виду злочинності, будь те жіноча, рецидивна, організована, насильницька чи корупційна, визначаються специфічними ознаками і властивостями злочинних посягань. Поділ злочинності на види дозволяє, по-перше, конкретизувати вивчення багатьох проблем: дати докладну характеристику тим або іншим злочинам, виявити їхні відмінні риси і властиві їм закономірності, що не представляється можливим при вивченні всієї злочинності взагалі; по-друге це необхідно для ефективного рішення практичних задач протидії кожному окремому виду злочинів і відповідно злочинності в цілому.

Однак, дослідження окремих видів злочинності ускладнюється поєднанням у одному виді злочинності декількох специфічних ознак. Яскравим прикладом цього, можуть служити прояви організованої злочинності працівників правоохоронних органів. Складність дослідження даного виду злочинності та, відповідно, розробки ефективних заходів протидії обумовлюється не лише вчиненням злочинів представниками стійкої, соціально-корпоративної, відособленої групи осіб - працівниками правоохоронних органів, але й організованою формою їх злочинної діяльності.

\section{Аналіз публікацій з досліджуваної проблеми}

У вітчизняній науці різні аспекти попередження протиправної поведінки працівників правоохоронних органів досліджувалися у роботах М. І. Ануфрієва, О. М. Бандурки, В. П. Ворушила, О. Ф. Гіди, О. А. Мартиненка, О. С. Новакова, О. Ю. Синявської, С. С. Сливки, C .А. Шалгунової та ін. Однак, незважаючи на виключну суспільну небезпеку організованих форм злочинності працівників 
правоохоронних органів, ця проблема ще не була предметом окремого дослідження.

\section{Мета статті}

Встановлення особливостей проявів та детермінації організованої злочинності працівників правоохоронних органів. Її новизна полягає у тому, що акцентована увага на існуванні організованих форм злочинності працівників правоохоронних органів, встановлені та проаналізовані деякі основні фактори детермінації даного виду злочинів.

\section{Виклад основного матеріалу}

Вітчизняна правоохоронна система, як і правоохоронні системи інших пострадянських країн стикнулася 3 появою все нових форм злочинної діяльності правоохоронців. Так, органи внутрішніх справ України сьогодні мають справу 3 новими формами протиправної діяльності у вигляді організованої „міліцейської” злочинності, прихованої підприємницької діяльності, свідомого зрадництва інтересів служби з корисливих спонукань, участі ряду працівників у незаконному обігу наркотиків та зброї. I хоча офіційні цифри зазначених видів злочинної діяльності є незначними (в середньому по 2-3 \% для України та РФ), однак їхне існування викликає серйозний громадський резонанс та стурбованість керівництва МВС [1, с. 125]. Високий рівень злочинів, вчиняємих у групі, вказує на те, що злочинність працівників ОВС набуває більш організованих форм, а це не може не викликати серйозну стурбованість керівництва МВС України [2, c. 45-46]. Як в Україні, так і у сусідніх країнах з'являються та успішно функціонують злочинні групи, що складаються 3 працівників ОВС, які вчинили добре сплановані і підготовлені злочини. Спрямованість злочинної діяльності такого роду груп досить різнобічна і включає весь спектр посягань, у тому числі й участь у вчиненні особливо тяжких злочинів (від сприяння у зміні запобіжних заходів і припинення кримінальних справ щодо злочинців до вимагання, викрадення людей, вбивства на замовлення та ін.) [3, с. 107; 4, с. 73].

У країнах колишньої соціалістичної орієнтації найпоширенішими формами по- ліцейських правопорушень $є$ корупція й зловживання службовим становищем. Опитування інституту Геллапа, що проводилося у 2001 р., виявило, що поліцейські Хорватії, разом із офіцерами митниці й лікарями 6 найбільш корумпованими чиновниками в країні, хоча за офіційною статистикою на їх частку припадає лише 1 \% всіх справ, порушених за фактами хабарництва та корупції. В Болгарії, після розпуску значної частини силових відомств, суспільство зіштовхнулося із проблемою злочинності, породженої колишніми співробітниками міліції й держбезпеки. Вже у 1991 р. близько 17 тисяч колишніх правоохоронців зайняли провідну роль у тіньовій економіці й курортному бізнесі, активно втягуючи в процес незаконного товарообігу решту колег, що створило, по суті, специфічну форму поліцейської організованої злочинності. У Російській Федерації спостерігається аналогічний феномен - на тіньовому ринку групи корумпованих співробітників міліції успішно конкурують із кримінальними угрупованнями, не тільки допомагаючи правопорушникам уникнути правосуддя, але й забезпечуючи комерційні структури такими „послугами”, як нелегальний захист, повернення боргів силовими методами, усунення конкурентів, надання оперативно-службової інформації. При цьому спостерігається активна участь у вчиненні злочинів керівного складу підрозділів [1, c. 157-158].

Однак, особливе занепокоєння викликає той факт, що організовані форми злочинної діяльності характерні не лише для вчинення корупційних та інших службових злочинів працівників правоохоронних органів. Груповий характер вчинення злочинів, нажаль, властивий й чималій частині насильницьких злочинів, вчиняємих даною категорією осіб. Так, 57 \% насильницьких злочинів вчинено працівниками ОВС в групі, що обумовлюється передусім характером і специфікою службових функцій, що виконуються працівниками ОВС, та підкреслює підвищену суспільну небезпеку такого роду злочинів. У 44 \% випадків насильницькі злочини вчиняються групою у складі всього двох осіб. У 35,6 \% випадків група налічує три особи, а в $6 \%$ випадків чотири особи. Вчинення ж 
групових насильницьких злочинів групою, кількість учасників якої складала п'ять і більш осіб, виявлено в $15 \%$ випадків.

У групі вчиняється абсолютна більшість грабежів (91\%) (у $15 \%$ випадків чисельність груп складає чотири і більше особи), також абсолютну більшість розбоїв (у $35 \%$ випадків чисельність груп складає три і більше особи) та 87,5\% вимагань. Крім того, працівниками ОВС в групі вчиняється 66,6 \% згвалтувань (22 \% - у групі з трьох осіб), 63 \% тілесних ушкоджень (15\% - у групі, що складається 3 трьох і більш осіб) та $34 \%$ вбивств.

Слiд звернути увагу на той факт, що $77 \%$ випадків злочинні групи складаються тільки 3 працівників органів внутрішніх справ, причому у 62,5 \% випадків співучасниками насильницьких злочинів є працівники однієї служби або підрозділу. У 14,5 \% випадків співучасниками виступають працівники різних служб і підрозділів ОВС. Вчинення насильницьких злочинів працівниками ОВС в співучасті з цивільними особами має місце у $23 \%$ випадків [5, с. 75-76].

Розглядаючи проблему організованих проявів злочинності працівників правоохоронних органів, слід враховувати, що працівники зазначених органів виступають не лише у ролі організаторів, керівників та учасників суто «міліцейських» злочинних об'єднань, або злочинних об'єднань з залученням цивільних осіб. Працівники правоохоронних органів також активно залучаються до членства в різного роду існуючі злочинні об'єднання або сприяють їх членам та укривають їх злочинну діяльність.

У всіх випадках складність протидії організованій злочинності працівників правоохоронних органів обумовлена, перш за все, специфікою суб'єкта злочинів. Саме в силу специфіки службового статусу працівники правоохоронних органів мають реальні можливості для провадження тривалої безкарної злочинної діяльності. Адже працівник правоохоронного органу наділений у рамках закону специфічними повноваженнями, володіє відповідними знаннями, навичками та засобами тощо. Таким чином, злочинна діяльність здійснюеться особами, які, як правило, володіють знаннями кримінального, кримінально-процесуального закону, а також володіють спеціальними навичками (у тому ж числі оперативно-розшукової діяльності) та вміннями, які вони можуть використовувати як при вчиненні злочину, при прихованні своєї участі в злочині, слідів злочину тощо.

Працівники правоохоронних органів володіють певною закритою інформацією, отриманою у зв'язку з виконанням професійних функцій, яку можна використовувати в організованій злочинній діяльності (наприклад, дані щодо потенційних жертв злочинів, про угруповання «конкурентів»; можливі канали збуту цінностей, отриманих злочинним шляхом; канали придбання зброї тощо). Професійні навички оперативнорозшукової діяльності можуть бути використані членами ОЗГ при підготовці до вчинення злочинів, а також здійснення з метою забезпечення функціонування злочинного угруповання функцій розвідки та контррозвідки (на досить високому професійному рівні здійснювати зовнішнє спостереження, прослуховування телефонів, іншим чином збирати інформацію про об'єкти тощо); навички слідчої роботи, знання всіх тонкощів розслідування того або іншого виду злочинів суттєво полегшують приховування слідів такого злочину, а також грамотно побудову системи ефективної протидії його розкриттю. Крім того, наявність численних зв'язків у правоохоронних та інших державних органах дозволяє отримувати необхідну злочинцям інформацію, а також вирішувати проблеми організованого злочинного угруповання [6, с. 104-105].

Стосовно особливостей детермінації збільшення проявів організованої злочинності працівників правоохоронних органів, одним із домінуючих факторів, на наш погляд, є дефіцит кадрів в правоохоронних органах, недоліки кадрового відбору та, як наслідок, потрапляння на службу в органи осіб з кримінальною спрямованістю особистості, а також недосконалість методик їх виявлення.

В наслідок існуючих недоліків кадрового відбору на службу в правоохоронні органи потрапляють не лише особи, які не відповідають вимогам до кандидатів на службу, але й особи з кримінальною спрямованістю осо- 


\section{Кримінальне право, кримінальний процес та криміналістика}

бистості, для яких служба в органах є лише засобом здійснення злочинної діяльності. Саме недосконалість методик виявлення зазначених осіб як при прийнятті на службу, так й під час їі проходження є детермінантою існування організованої злочинності працівників правоохоронних органів.

Масштаб цих недоліків у перші роки здобуття незалежності сягав такого рівня, що на службу до органів внутрішніх справ України потрапляли особи, раніше засуджені за вчинення злочинів, а повторне засудження цих осіб за злочини, вчинені в період проходження служби, наочно демонструє криміногенний потенціал подібних вад кадрового апарату.

Так, міліціонер-водій ППСМ О., будучи в складі патруля (4 працівники), одержавши інформацію про квартиру, де нібито продаються наркотики, разом зі всіма членами патруля, нікого не повідомивши, відхилився від маршруту. Працівники переодяглися в цивільний одяг і зайшли до квартири громадянина Г. Погрожуючи табельною зброєю (автоматом і пістолетом), закували присутніх осіб у наручники й провели несанкціонований обшук, у результаті якого вилучили гроші, речі, наркотики, після чого відібрали в потерпілих паспорти; зажадавши за повернення документів і непритягнення до відповідальності хабар, працівники органів внутрішніх справ залишили квартиру. Суд визнав О. винним за ч.2 ст. 168, ч. 2 ст. 140 , ч. 2 ст. 166 КК УРСР 1960 p. (ч. 2 ст. 17-368, ч.2 ст. 185, ч. 2 ст. 365 УК України 2001 р.) і засудив до 6 років позбавлення волі з конфіскацією майна. Аише під час слідства було встановлено, що О. вже був раніше засуджений за ч. 2 ст. 193 КК УРСР 1960 р. (ч.2 ст. 357 УК України 2001 р.) до 1 року позбавлення волі [7].

Слід зазначити, що проблема потрапляння на службу до правоохоронних органів осіб з кримінальним минулим є актуальною не лише для України. Так, за даними Головного управління кадрів МВС РФ за 2001 рік, лише у УВС Кемеровської області було виявлено 22 працівника органів внутрішніх справ, що мали судимість до вступу на службу $[8$, с. 75$]$.

Одним із специфічних факторів детермінації організованої злочинності працівників правоохоронних органів є гіпертрофована професійна корпоративність працівників правоохоронних органів.

Корпоративність працівників правоохоронних органів багато в чому обумовлена специфікою діяльності, круговою порукою, захисним механізмом самовиправдання. Притягнення до відповідальності далеко не кожного $з$ працівників, які вчинили злочини, почасти є результатом саме корпоративності в широкому розумінні - викривленої „солідарності” юристів, які зневажливо ставляться до порушення законності своїми колегами [9, с. 600]. Тобто, у даному випадку йдеться насамперед про те, „що помилково розуміється як „солідарність”. Як відзначають фахівці, найчастіше відчуття корпорації (з відповідним конструктивним протиставленням „ми” і „вони”) не може бути негативним явищем. Однак будучи гіпертрофованим, зазначене протиставлення породжує різного роду службові зловживання. При цьому, як слушно зауважує О.А. Мартиненко, „чесність і принциповість у взаємовідносинах співробітників поступаються лояльністю, коли будь-які вчинки схвалюються, якщо вони скоєні „своїми”. ... Такі явища зазвичай спостерігаються у ситуаціях безпринципного захисту „честі мундиру”, коли протипоставляються співробітники міліції простим громадянам” [10, с. 282]. Проблема існування так званого „кодексу мовчання” характерна для поліції багатьох країн. Той, хто дає свідчення на іншого поліцейського під час розслідування, не допускається до участі в неформальному житті поліції, з ним вже ніхто не буде співпрацювати. Тому негідна поведінка поліцейських лише у поодиноких випадках стає відомою правосуддю [3, с. 81].

Слід враховувати, що негативна корпоративність працівників правоохоронних органів щодо девіантної поведінки колег формується, нажаль, ще на стадії професійного навчання. Так, наприклад, опитування випускників ВНЗ МВС України, проведене нами, виявило, що кожний четвертий працівник органів внутрішніх справ ще на самому початку кар'єри не лише лояльно ставиться до вчинення колегами насильницьких злочинів, але й готовий активно підтримувати 
такі дії. Так, на запитання „Які будуть Ваші дії, якщо Ваш колега вчинить насильницький злочин?”, ми отримали наступний розподіл відповідей: запропоную йому з'явитися в прокуратуру із зізнанням (12\%); запропоную йому з'явитися до безпосереднього начальства із зізнанням (40\%); сам повідомлю прокурора $(2,6 \%)$; сам повідомлю безпосереднє начальство $(5,8 \%)$; не буду звертати на це ніякої уваги (14,5 \%); зроблю все, щоб про це ніхто не дізнався (13\%).

Далі в практичній діяльності такі негативні професійні установки знаходять реальне відображення, що підтверджує той факт, що у 35 \% випадків насильницькі злочини вчиняються працівниками ОВС при наявності свідків-колег, причому в 30 \% випадків - свідки схвалюють або заохочують до продовження злочинних дій [5, с. 101-102]. Крім того, часто молоді працівники, навіть розуміючи протиправність дій старших товаришів зі служби, не хочуть загострювати, а то й псувати 3 ними стосунки, тому самі стають співучасниками злочинів.

Що стосується механізму залучення працівників правоохоронних органів до організованої злочинності, то слід відзначити, що ще в середині 70-х рр. західними фахівцями було сформульовано теорію соціального навчання, відповідно до якої іï автор, $\lambda$. Шерман, розглядає факт моральної деградації поліцейських як результат тривалого, багатоступінчастого процесу соціального навчання 3 поступовим засвоєнням індивідом негативних групових норм, що існують у тому чи іншому поліцейському підрозділі. На перших стадіях молоді поліцейські під впливом своїх старших колег привчаються до терпимого ставлення до незначних відступів від закону іншими поліцейськими. Надалі в них виробляється переконаність у тому, що без „зрізання кутів” та деяких перегинів здійснення ефективної поліцейської діяльності є просто неможливим. Потім молодий поліцейський проходить стадію, на якій він звикає до різного роду дрібних послуг, що надаються йому власниками магазинів і ресторанів -безкоштовного сніданку, продажу продуктів чи товарів зі значною знижкою тощо. Виправдуючи свої дії тим, що він просто приймає знаки подяки від громадян за свою нелегку роботу, поліцейський під патронатом знов таки старших колег розширює коло своїх дій, що суперечать закону. За окрему винагороду він починає надавати приватним особам додаткову охорону, сприяє в усуненні торгових конкурентів, закриває очі на деякі правопорушення й у ряді випадків допомагає уникнути певним особам відповідальності перед законом. На цій стадії поліцейський просто приймає незаконні винагороди або послуги і підпадає під категорію „травоїдних” поліцейських, тобто осіб, які спокійно „пасуться” на своїй території та приймають винагороди від громадян як щось, надане природою. Остання стадія моральної деградації поліцейського характеризується перетворенням його 3 „травоїдного” на „хижака”, коли він починає активно шукати джерела незаконного збагачення. Саме на цій стадії поліцейський робить свідомий крок назустріч кооперації 3 організованою злочинністю, зраджує інтереси служби і стає закінченим „продажним поліцейським" [1, с. 175-176].

Хоча офіційні дані судової практики та відомчої статистики вказують на зовсім незначний рівень організованої злочинності працівників правоохоронних органів, дана проблеми викликає чимале занепокоєння. Так, опитування колишніх працівників правоохоронних органів, засуджених за вчинення злочинів, проведене Ю.В. Стрелковською, показало, що більшість опитаних осіб мали справу з представниками організованої злочинності під час роботи в правоохоронних органах $(51,7 \%$ - у зв `язку з оперативною роботою; 24,1\% - у зв язку з роботою у карному розшуку; 5,1\% - при проведенні слідства по кримінальній справі; 10,3 \% інше). Більше того, кожен четвертий респондент, що стикався під час роботи з представниками організованої злочинності, мав iз ними неформальні контакти поза службовими відносинами $(25,9 \%)$. Крім цього, більшість респондентів $(55,4 \%)$ зазначили, що їм також відомі випадки, коли представники організованої злочинності зверталися до правоохоронців за захистом (за так званою “кришею”). Найбільш це поширено серед працівників МВС - 53,1\%, із них: $42 \%$ - УБОЗу, 21\% - карного розшуку, 18,5\% - 
Кримінальне право, кримінальний процес та криміналістика

\section{АНОТАЦІЯ}

Акцентована увага на існуванні організованих фборм злочинності прачівників правоохоронних органів. Встановлені та проаналізовані деякі основні бактори детермінаціі даного виду злочинів.

ОБНОНу, 17,3\% - ОБЕЗу, 3,7\% - ОБШМ "Беркут". На другому місці по корупційним зв'язкам з організованою злочинністю знаходяться співробітники прокуратури $-42 \%$. Далі йдуть працівники СБУ - 30,9\%; судів $28,4 \%$; податкових органів $-7,4 \%$; митних та прикордонних органів - по 3,7\%. Біля третини опитаних (а саме $34,6 \%$ ) зазначили, що усі правоохоронні органи надають допомогу кримінальним структурам [6, с. 100].

\section{Висновки}

Викладене вище свідчить, що прояви організованої злочинності працівників правоохоронних органів, нажаль, мають не характер одиничних випадків, виключень, а свідчать про появу нових форм та негативні тенденції зміни кількісно-якісних характеристик злочинності працівників правоохоронних органів. Зазначене вказує на необхідність подальшого комплексного наукового дослідження даної проблеми з метою розробки системи заходів протидії цьому негативному явищу.

\section{Література}

1. Мартиненко О.А. Злочини серед працівників ОВС України: їх детермінація та попередження: дис. ... д-ра юрид. наук: 12.00.08 / Мартиненко О.А. - Х., 2007. $434 \mathrm{c}$.

2. Новаков О.С. Кримінологічна характеристика та профілактика злочинів, які вчиняються працівниками міліції у сфері службової діяльності: дис. ... канд. юрид. наук: 12.00.08 / Новаков О.С. - К., 2003. - 205 с.

\section{SUMMARY}

Attention on existence of the organized forms of criminality of workers of law enforcement authorities is accented. Set and analysed some basic factors of determination of this type of crimes.

3. Алтухов С.А. Преступления сотрудников милиции (понятие, виды, особенности профилактики) / Алтухов С.А. - СПб.: Издательство «Юридический центр Пресс», 2001. $-271 \mathrm{c}$.

4. Современные проблемы и стратегия борьбы с преступностью / Науч. ред. В.Н. Бурлаков, Б.В. Волженкин. - СПб.: Издательский Дом С.-Петерб. гос. ун-та, Издательство юридического факультета С.Петерб. гос. ун-та, 2005. - 592 с.

5. Ігнатов О.М. Насильницькі злочини, що вчиняються працівниками органів внутрішніх справ України: кримінологічна характеристика, детермінація та попередження: монографія / Ігнатов О. М. - Харків: Формат Плюс, 2008. - 293 с.

6. Стрелковська Ю.О. Маргінальні групи в структурі організованої злочинності: кримінологічне дослідження: дис... канд. юрид. наук: 12.00.08 / Стрелковська Ю.О. - О., 2008. - 249 c.

7. Вирок Шевченківського райсуду м. Києва від 13.11.1995 р. - Справа № 1-385.

8. Кондаков А.В. Предупреждение нарушений законности в правоохранительной деятельности милиции: дис. ... канд. юрид. наук: 12.00.01 / Кондаков А.В. - Саратов, 2006. - 230 c.

9. Криминология: Учебник / Под. ред. В.Н. Кудрявцева, В.Е. Эминова. - М.: Юристь, 2004. - 734 с.

10. Мартыненко О.А. Детерминация и предупреждение преступности среди персонала органов внутренних дел Украины: Монография / Мартыненко О.А. - Х.: Издво ХНУВС, 2005. -468 с. 